\title{
Jack Goody: The Anthropology of Unequal Society
}

\author{
Keith Hart* \\ Goody, J. 2004. Capitalism and Modernity: The Great Debate. Cambridge: Polity.
}

Goody, J. 2004. Islam in Europe. Cambridge: Polity.

Goody, J. 2012 [2006]. The Theft of History. Cambridge: Cambridge University Press.

Goody, J. 2009. The Eurasian Miracle. Cambridge: Polity.

Goody, J. 2010. Renaissances: The One or the Many? Cambridge: Cambridge University Press.

Goody, J. 2012. Metals, Culture and Capitalism: An Essay on the Origins of the Modern World. Cambridge: Cambridge University Press.

*Address correspondence to Keith Hart, 135 rue du Faubourg Poissonniere, 75009 Paris, France. E-mail: johnkeithhart@gmail.com

In almost four decades Jack Goody has published a score of books seeking to explain the divergence of Africa from the Eurasian continent, and latterly to refute historical claims of western superiority to Asia. Since the millennium, he has sought to clarify his own vision of modern capitalism at a time when western hegemony is coming under pressure from globalization. Yet this achievement has not received the recognition from anthropologists that it deserves. This article, in reviewing six books published during the last decade, makes a case for reassessing Goody's project from the mid-1970s until now. It singles out two books for special attention, The Theft of History and his latest volume, Metals, Culture and Capitalism. A consistent theme of his recent work is to juxtapose his own account of the history of western capitalism with those of Marx, Weber and other writers in the classical tradition of social theory. Jack Goody remains to this day an anthropologist whose 
sensibility was formed by long-term ethnographic fieldwork. But he knew that, if he aspired to throw light on the human predicament as a whole, he would have to become a world historian too.

Keywords: capitalism, Eurasia, metals, Renaissance, the West, world history

Sir Jack Goody turns 95 this year. This review examines a half dozen books that he has written in the last decade, of which Metals, Culture and Capitalism (2012) has a claim to being the most synthetic in a remarkably wide-ranging series of historical comparisons that was launched almost four decades ago. The subtitle of this latest book-An Essay on the Origins of the Modern World-makes explicit a growing focus of his writing since the millennium. Hitherto Goody's subject matter was the pre-industrial societies of the Old World; but now he wants to clarify how he distinguishes his own historical vision of modern capitalism from theories of Western monopoly that are increasingly coming under pressure from globalization.

Despite - or perhaps because of - the abundance and scope of his writing, Goody's work is not widely known or cited by Anglophone anthropologists today. He has not left a school of followers; indeed it is hard for the rest of us to catch up with his fast-growing output. He was my teacher and, in time, I have come to recognize his massive influence on my own development as an anthropologist. But there is still much to learn from him. Jack Goody links the past to the future in ways that his contemporaries find it hard to absorb in the present.

This review article has four sections. Part 1 summarizes Goody's project from the mid-1970s to around the millennium. The Eurasian Miracle provides a retrospective road map to this project. Part 2 focuses on The Theft of History and, to a lesser extent, two related texts, Islam in Europe and Renaissances. Part 3 examines how Goody places Western capitalism in world history, as revealed initially by Capitalism and Modernity and now by Metals, Culture and Capitalism. Part 4 concludes by assessing Jack Goody's contribution to anthropology.

\section{Jack Goody's vision of world history}

In a short preface to the first in his series of comparisons between Africa and Eurasia, Jack Goody (1976: ix-x) tells us that ethnography, the aspiration to write about another culture studied intensively through fieldwork, never defined his intellectual horizons. His subject is historical comparison and beyond that "the development of human culture." He deliberately sets himself at odds with his greatest contemporary, Claude Lévi-Strauss (1962), as being uninterested in binary oppositions between the modern and the 
primitive. Rather, he places himself as an actor in a historical period, coming of age in the Second World War, encountering the Eastern Mediterranean, escaping from a prison camp into the mountains of Abruzzo, entering Africa at the decisive moment of its anti-colonial revolution and in its epicenter, Ghana. With European empires collapsing everywhere, he has always rejected the Euro-centric idea that the West is special, looking instead for forms of knowledge that are more truly universal, better suited to the new world society launched by the war.

As a former student of English literature, he knew something about medieval European society and culture. He wanted to connect a newly independent West Africa to the Islamic civilization he encountered briefly during the war. His subject was therefore the comparison of pre-industrial societies, past and present, an ethnographically informed juxtaposition of Africa, Europe, and the Middle East. Then and now, he stresses that his research is an extension of his own personal experience, fueled by social interaction and political engagement. For example, he traces his interest in minerals to signing up for a regiment of Nottinghamshire miners in the Second World War. The ultimate historical question is where human civilization is going, but the key lies in the similarity and divergence of regions with an agrarian past. Only a series of books could begin to address this question. The full title of the first was Production and Reproduction: A Comparative Study of the Domestic Domain. His focus here was on how human beings produce their livelihood within families and how this influences attempts to secure their future. But Death, Property and the Ancestors (1962) remains his key work. The three themes of the title-how we seek to transcend death materially and spiritually-come together in Goody's preoccupation with writing itself, a project he launched with The Domestication of the Savage Mind (1977).

How does Jack Goody's project of historical comparison illuminate the world society emerging in our time? What is his vision of the development of human culture, past, present, and future? Think what the human condition was like in 1945 and what it is now. Something tremendous has happened in between. Humanity has been brought closer together in dramatic ways. Seven billion of us have formed world society as a single interactive network for the first time. This society is massively unequal and riddled with conflict, but now at last there is a universe of communications to give concrete expression to universal ideas. Future generations will want to study this emerging human society and they will look to us for clues; but they will be disappointed by the fragmented narrowness of our anthropological vision.

Anthropologists, in sticking with the ethnographic method, have not risen to the challenge of documenting this huge shift in civilization. Jack Goody could not settle for just getting to know another culture. He rather devised and carried out an anthropological project with a scale to match 
the world society being formed in his day. In reaching for a more universal conception of human history, he knew that he was an active participant in the making of a new world. But, even as he inserted himself into contemporary society, he chose to step back from the modern age. Initially he left out any direct consideration of two centuries of machine revolution, the capitalist world economy, the New World in its entirety. His topic is nevertheless the development of human culture and his recent writing reveals even more sharply than before that his inquiries do reflect a consistent position on the social priorities of our times.

A few years after his wartime sojourn in the Mediterranean basin, Jack Goody carried out research in West Africa, a region connected to the Mediterranean by Islamic civilization long before it was colonized by Europeans. On the basis of extensive fieldwork in Northwest Ghana before that country won independence from colonial rule, he soon established himself as a force in West African anthropology, first as an ethnographer and later as a historian (Hart 1985). Goody was impressed, however, by the similarities and differences between Africa, Europe, and the Islamic world. It took him three decades to formalize the terms of comparison; but, when he did, it turned out as follows: Europe may be opposed to Asia as West to East, but the two should be seen as a single entity, Eurasia, contrasted in turn with Africa South of the Sahara. This model rejects the dominant imperialist stereotype, which opposes the West to the Rest. If there is one constant in his work, it is a profound dislike of racist binaries privileging Western leadership of the world that their colonial empires made.

Goody started with kinship and marriage, the domestic relations though which people manage their own reproduction and participate in the wider society. In Death, Property and the Ancestors (1962), he concluded that the key to variations in kinship organization lay in the transmission of property, the material link between generations constituted by patterns of inheritance and manifested in religious observances such as the ancestor cult. The book drew extensively on classical sources of British comparative jurisprudence; but Goody balked at making a systematic comparison of Africa and Europe then. In Tradition, Technology and the State (1971), he questioned the habit of transferring categories from European history to the study of pre-colonial states in Africa. Once again his focus was on property forms. European feudalism was based on private property in land and this was absent from traditional West Africa. Why? Because land was scarce in Western Europe, but not in Africa, where the scarce factor was people; and control over them was exercised through monopolies of the "means of destruction" (horses, guns, etc.), not the means of production. Africa's polities were both centralized and decentralized, the former acquiring manpower by force through carrying out slave raids on the latter (Fortes and Evans-Pritchard 1940). Shifting hoe agriculture was the norm, with the bulk of manual labor being performed by women. In both types of society they were hoarded as wives by polygamous older men 
and their children were recruited to exclusive descent groups. The key to major differences in social organization between Africa and Eurasia thus lay in the conditions of production and specifically in demography, in the ratio of people to the land.

Production and Reproduction takes off from this premise into a global survey of kinship, marriage, and property transmission, using the data compiled by G. P. Murdock's Ethnographic Atlas, 1962-1980 (Murdock 1967). Kin groups in the major societies of Eurasia frequently pass on property through both sexes, a process of "diverging devolution" (including bilateral inheritance and women's dowry at marriage) that is virtually absent in Africa South of the Sahara, where inheritance follows the line of one sex only (Hann 2008). Especially when women's property includes land, attempts will be made to control these heiresses, banning premarital sex and making arranged marriages for them, often within the same group and with a strong preference for monogamy. Direct inheritance by women is also associated with the isolation of the nuclear family in kinship terminology, where a distinction is drawn between one's own parents and siblings and other relatives of the same generation, unlike in lineage systems. All of this reflects a class society. "Diverging devolution (especially dowry) [is] the main mechanism by which familial status was maintained in an economically differentiated society" (Goody 1976:19).

Why should the African and Eurasian patterns be so different? I suggest that the scarcer productive resources become and the more intensively they are used, then the greater the tendency for the retention of these resources within the basic productive and reproductive unit, which in the large majority of cases is the nuclear family .... Advanced agriculture, whether by plough or irrigation, permits an individual to produce much more than he can consume.... [T] he greater volume of production can maintain an elaborate division of labor and stratification based upon different styles of life. An important means of [this] ... is marriage with persons of the same or higher qualifications.... Advanced agriculture [also] allows the expansion of population, another factor making for scarcity of land" (Goody 1976: 20).

The agrarian economies of all the major Eurasian civilizations conformed to this pattern. They were organized through large states run by literate elites whose lifestyle embraced both the city and the countryside. This is Gordon Childe's (1942) "urban revolution" in Mesopotamia 5,000 years ago. Africa South of the Sahara apparently missed out on these developments. By starting from the relationship between types of property transmission and forms of kinship and marriage, Goody arrived at a new synthesis of the agricultural roots of civilization.

The intellectual legacy of imperialism still underpins anthropology today. So Jack Goody chose to attack the lingering opposition of "modern" 
and "primitive" cultures by studying the chief activity of literate elites, of which he was himself a leading example-writing. Contrasting mentalities should be seen as an effect of different means of communication. The most important of these are speech and writing. Most African cultures are predominantly oral, whereas the ruling classes of Eurasian civilization have relied from the beginning on literate records. His most general assault on the habit of opposing us and them, The Domestication of the Savage Mind (Goody 1977), came out a year after Production and Reproduction. This was a pointed repudiation of La Pensée Sauvage of Lévi-Strauss (1962), suggesting that the latter's lists linking "hot" and "cold" societies to other pairs, such as history and myth, science and magic, far from exemplifying universal reason, were a parochial by-product of mental habits induced by writing. Literacy was thus a key feature of the institutional complex that marked the urban revolution.

Accordingly, while rejecting most of the binary contrasts that underpin modern civilization, Jack Goody rests his own case on another. The Great Divide in human history was the Bronze Age urban revolution and its culture founded on writing. The initial geographical contrast between Eurasia and Africa served to highlight this division. Nothing that has happened since is as important. In The East in the West (1996) and all the books reviewed here, Goody has sought to refute the claim, cherished by the founders of modern social theory, that the West's economic ascendancy, driven by capitalism, could be attributed to a unique type of rationality missing from the less fortunate societies, specifically from Asia. He argues that Europe's distinctiveness is either non-existent or has been exaggerated, while the rate of adoption of Western industrial techniques by Asian societies has been faster than it took for the innovations of the Italian Renaissance to diffuse to Northwest Europe. It makes more sense to see Eurasia as a single entity, with the advantage fluctuating between regions over time in an unstable pattern. Africa, whose exceptional character remains unchallenged so far, tends to drop out of view in his recent publications (Hart 2011a). The rise of China and India as capitalist powers, following Japan, has only reinforced Goody's argument.

According to Jack Goody, the relative standing of Eurasia's regions has fluctuated over 5,000 years, with Western Europe (and its North American offshoots) enjoying some advantage since the Renaissance, especially since the industrial revolution. He utterly rejects any claim that Asia was ever structurally inferior. In most respects, Asian civilizations were well ahead of Europe for much of history. The speed with which they have adopted modern capitalism points to a fundamental similarity that helps us to understand the reversal in economic dominance that is under way now.

Goody set out to deconstruct the racist binaries that organize so much thinking about anthropology and world history. It is better to consider how institutional patterns vary in emphasis and combination. Then the grounds for racial superiority are undermined and economic development is seen less readily as a series of radical breaks. Goody explains cultural difference by 
technological change, but is open to recognizing influences in the reverse direction (see Part 4 below). The intensification of agriculture (the plough and irrigation) and new means of communication (writing) underpin the unequal class structure of agrarian civilization and explain the cultural differences between Eurasia and Africa. So Western supremacists are not only mistaken in assuming Europe's uniqueness, they are idealists who fail to grasp the material conditions underlying the cultural differences that they celebrate.

Modern ethnographers too have criticized Western complacency, but their examples have generally been taken out of the context of world history. Jack Goody has excavated a new anthropological vision of our world that is bound to become even more salient as the present century unfolds. He stands squarely in a tradition that might be called "the anthropology of unequal society," drawing initially on Marxist pre-historian Gordon Childe's materialist synthesis of the great revolutions that marked the history of human production and society. Childe got his basic framework from L. H. Morgan's Ancient Society (1877), which some have seen as the origin of modern anthropology. This work was made more widely accessible by Friedrich Engels as The Origin of the Family, Private Property and the State (1884). But Morgan-Engels got it in turn from Jean-Jacques Rousseau (1754), whose Discourse on the Origins and Foundations of Inequality among Men is the source for this tradition. Its leading practitioner of late has been Jack Goody (Hart 2006; Hann and Hart 2011:10-12).

Despite a consistent barrage of propaganda telling us that we now live in a modern age of science and democracy, humanity's dominant institutions are still those of agrarian civilization: territorial states, embattled cities, landed property, warfare, racism, bureaucratic administration, writing, impersonal money, long-distance trade, work as a virtue, world religion, and the nuclear family. This is because the rebellion of the Western middle classes against the Old Regime was co-opted by that synthesis of industrial capitalism and the nation-state that I call "national capitalism" (Hart 2009); and emancipation from unequal society has suffered reverses as a result. Consider the shape of world society today. A remote elite of white, middle-aged, middle-class men, "the men in suits," rule masses that are predominantly poor, dark, female and young. Citizens of the rich countries, who can no longer reproduce themselves, marginalize the migrants seeking economic improvement who work for their pensions. Our world resembles nothing so much as the Old Regime in France before the revolution, when Rousseau wrote his Second Discourse. Africa is the most poignant symbol of this unequal world; but that may be changing (Hart 2010, 2011a).

Jack Goody has been telling us something about the formation of contemporary world society. Like Bruno Latour (1993), he says that we have never been modern. Modern democracy is predicated on the abolition of the unequal society that ruled the Eurasian landmass for 5,000 years. He reminds us of the durable inequality of our world and suggests that its causes may be 
less tractable than we think. At the same time, the rise of China and India underlines his warning against European complacency. The world is now simultaneously more connected than ever and highly unequal, a dangerous combination. The reduction of national political controls over global markets in the last three decades has accelerated the gap between the haves and have-nots everywhere, generating huge regional disparities in the process. Redress for this situation seems further away today that it did in 1945, when Jack Goody set out on his post-war journey.

To recap, the key to understanding social forms for Jack Goody lies in production. Civilization or human culture is largely a consequence of the means of communication - once writing, now an array of mechanized media, but always interacting with oral and written forms. The site of social struggles is property, now often intellectual property. His central focus on reproduction has never been more salient as the ageing citizens of rich countries confront the proliferating mass of young people out there, most of them from Asia and Africa. Kinship needs to be reinvented too. If human culture is to be rescued from the unequal society that results when agrarian civilization adopts modern machines (see Part 3 below), Jack Goody's anthropological vision offers one way of contemplating how.

The Eurasian Miracle (2009) provides a road map to Goody's vast canvas, now spread over a score of volumes. It is almost as if a great painter wrote the catalogue for an exhibition of his life's work. This small book documents the main areas in which he has sought to dismantle the evolutionist myth of Europe's unique historical path. These are: kinship, the family and individualism; urban commerce; the puritan roots of capitalism; and communications technology. He thinks too much has been made of the industrial revolution as a decisive break in history; that modern capitalism may not be so radically different from its predecessors; and that attempts to associate recent history exclusively with the achievements of the West are deluded. He obviously feels that the contrast between Old and New Worlds is exaggerated, since he never contemplates the Americas. Many of the features taken to be culturally distinctive of particular regions (notably Europe) may be found elsewhere, often in quite well-developed forms. So, rather than classify whole societies according to the presumed presence and absence of cultural traits, it is better to consider institutional variation between them as a matter of emphasis and combination. In this way the core grounds for racial superiority are undermined and economic development should be less readily conceived as a series of radical breakthroughs.

\section{The theft of history}

Jack Goody's The Theft of History (2006, republished as an attractive paperback in 2012) is the outstanding publication of this recent crop. In 
1900, about four-fifths of the planet's inhabited land was controlled by people of European origin. Although European expansion was by then four centuries old, this land grab had largely taken place in the previous half-century, and for most of Africa in the last two decades. It was manned by the world's first population explosion, when European death rates fell faster than birth rates from the 1830s, and was enabled by rapid improvements in technologies for inflicting death on others. It is hardly surprising that the Europeans asked themselves how they came to enjoy what sometimes seemed like an effortless superiority over all comers. This was also the time when modern anthropology was born with the aim of finding answers.

The means now seems obviously enough to have been industrial capitalism, that combination of big money and machine production that took off around 1800 in Britain and a few other places. But where did this come from? Europeans supposed that something in their culture must account for their successful application of scientific rationality to the task of world domination. Soon enough this cultural perception was given a biological foundation as a racial hierarchy with whites at the top, blacks at the bottom, and yellow, red, and brown people in between. So, when world society was launched by Western imperialism in the course of the nineteenth century, it took the highly unequal form of a racial order, which most people had been coerced into joining. Not only the anthropologists, but Western historians, philosophers, and social theorists set out to explain this European triumph in selfcongratulatory terms. And most of them are still content to do so.

Jack Goody does not seek in The Theft of History to account for Eurocentrism as such, but rather to demolish its pretensions to intellectual respectability. He sets out to show that, in order to turn a temporary success into an origin myth without end, even the most serious Western writers have unjustifiably traced Europe's global ascendancy back to the civilization of the Renaissance or to that of Ancient Greece. In separating Europe from Asia, the Middle East and North Africa, they have systematically downgraded Asian societies, while ignoring Eurasia's common foundation in Bronze Age civilization. Above all, as the first owners of a newly formed world society, they have rewritten history with themselves in the driving seat forever and have usurped the legitimate claims of others to have shared in humanity's greatest achievements. In other words, having stolen their land, the Europeans proceeded to steal their history also.

The book's chapters are organized in three groups of three, framed by an introduction, an essay on time-space, and an afterword. The first set examines the historical categories that allegedly account for Europe's divergence from Asia before the early modern period: Antiquity, Feudalism, and Asiatic Despotism. The second discusses three authors who have done much to shore up European assertions of their own uniqueness: Joseph Needham, Norbert Elias, and Fernand Braudel. The third deals with institutions, values, and even emotions for which Europeans have claimed a monopoly: towns and 
universities; humanism, democracy, and individualism; and love. Goody leans over backwards to be fair to his opponents, some of whom he clearly admires.

In Jack Goody's view, perhaps the most significant result of the West's global hegemony has been to impose a universal system of time-space on the rest of the world. The Theft of History kicks off with a brief sketch of how it came about, emphasizing the distortions of world history that have accompanied this development. Europe's claim to have diverged, via the ancient Greeks and Romans, from a Bronze Age civilization whose heartland was in Asia goes back to the Renaissance; but it took on particular salience in the age of Western imperialism. Goody sifts patiently through arguments for their unique achievements in culture, economy, politics, and law, showing that writers like Moses Finley (1973) and Karl Polanyi (1957) relied on arbitrary categories or invoked notions like genius to shore up inconsistent and erroneous propositions. He refuses, however, to go as far as Martin Bernal in Black Athena (1987) who derived much of Greek culture from Egypt and claimed that the separation of ancient Greece from the rest of the Eastern Mediterranean was an invention of racist imperialism in the nineteenth century. Goody maintains his distance from Bernal because, apart from feeling that his linguistic evidence is shaky, Europeans have no monopoly on ethnocentrism and they adopted racist attitudes to their Mediterranean neighbors long before they were in a position to conquer the world.

Perhaps the most bare-faced invention of Western philosophers and historians was to name the collapse of civilization after the fall of Rome "feudalism" and then to suggest that it provided a unique launching pad for capitalism. Goody, who long ago (1971) resisted the export of the feudal label to African polities, now convincingly undermines any such claim to distinctive progress, emphasizing rather medieval Europe's massive loss of standing when measured against the Asian societies of the period. Taking Perry Anderson (1974) to task, he also rejects the notion that Japan's early capitalist success had its roots in a similarly distinctive feudal past. The whole sorry attempt from the Renaissance onwards to create a single exceptional sequence for the West culminating in the triumph of freedom just does not add up. Its corollary is the notion that Asian societies as a whole were static for all this time, being hidebound by subservience to rulers unconstrained by law ("Oriental despotism"). Goody does not have much trouble disposing of that one.

He chooses three individuals to exemplify the trend he wishes to subvert and holds them in varying degrees of respect. Needham appears at first sight to be an unusual choice, since his multi-volume Science and Civilization in China (1954-2004) showed that Chinese technology was the equal of or better than Europe's up to 1600. But Goody takes issue with Needham's idea that the West took off on a trajectory uniquely its own since then. He has long been critical of Elias (1939) as the leading advocate of Europe's claim to have 
invented "civilization" starting with the Renaissance. Goody's arguments against the historical veracity of this claim echo earlier chapters, but an added note of asperity derives from the fact that they overlapped in Ghana soon after independence. Elias's comments then about an imagined "primitive" Africa provide Goody with further proof of his Euro-centrism. Who would deny Braudel's excellence as a historian? Jack Goody does not try to. Nevertheless, the trilogy Civilization and Capitalism, 15th to 18th Century (1981-1984) tries to establish that Europe was and is the original home of "true capitalism." Goody, with more support from Marx (1867) and Weber (1922) than he appears to realize, rejects the claim that this mercantile variant of capitalism was any different from many Asian examples going back to the Phoenicians. His suggestion elsewhere in the book that we might all be better off without Werner Sombart's (1902) coinage - capitalism — could be right.

Much of the argument concerning the West's claim to being the unique author of the modern world rests on a series of keywords, obviously Western in origin, whose universal aspirations and exclusivity Goody disputes. These include the occidental city and the bourgeoisie it nurtured (Weber 1978); associated institutions like the Western university and the forms of knowledge it generated; democracy and the idea of freedom; humanism, individualism, and romantic love. Goody provides an erudite if scattershot critique of all these claims, demonstrating that such concepts are not only vague beliefs, but that their institutional core is widely shared, especially by Islamic civilization, but even as far afield as Northern Ghana.

His "Last Words" offer a recapitulation of all this. The main pre-industrial civilizations of the Eurasian land mass have a common origin in the rise of cities, the state, and class society five millennia ago; and they grew side by side for most of that time, with first one area taking the lead and then the other, but without significant institutional divergence, certainly when contrasted with Africa. Goody's method has always been comparative sociology. He prefers to break down abstract cultural concepts into analytical frameworks that permit empirical investigation across a wide historical range of societies. He has chosen to restrict himself to the Old World and has largely by-passed the last two centuries of world history. His vision is one of durable continuities rather than of decisive breaks, at least since the urban revolution. Above all, he has tried to deconstruct the ideology of inevitable and eternal Western hegemony over the peoples of the world, nowhere more powerfully than in this book. Jack Goody's revisions of received opinion on Western pretensions to global leadership are invaluable; but they do not throw much light on the dynamics of modern world history. Several of the books reviewed here, however, not least the two considered in Part 3 below, reflect his growing awareness that he must clarify his position on the contemporary trajectory of global capitalism.

To return to the empirical fact of Western imperial domination in 1900, this can now be seen as the midpoint in an unparalleled transformation of 
world society over the last two centuries. In 1800, the world's population was around 1 billion, having grown slowly over 10 millennia of agricultural production; only 1 in 40 human beings then lived in an urban settlement; almost all the energy people used came from animals and plants; as Goody points out, China was still the world's economic powerhouse and Europeans had only a toehold on most of the planet. By 2000, the world's population had grown to 6 billion, doubling in the previous 40 years, while Europe's indigenous population went into reverse; almost half of humanity now lived in cities; and this was made possible by increased use of machines as converters of inanimate energy, once coal and now oil. The latest stage of mechanization is a digital revolution in communications whose symbol is the Internet. Before that, the most powerful social movement for a century had been the anti-colonial revolution - the drive of peoples forced into world society by Western imperialism to establish their own direct relationship to it. It seems quite plausible today that the United States and Europe could soon be replaced as the engines of world society by countries like India, China, and Brazil, whose peoples were not long ago subject to the kind of cultural condescension whose premises Goody undercuts so comprehensively in this book.

Reflecting a general trend in anthropology, Africa has dropped out of Goody's focus in favor of a critical attempt to get Western scholars to re-examine themselves and to acknowledge that the grounds for asserting a long-term superiority to Asia are non-existent. His earlier excursion into the history of the European family (Goody 1983) showed that Western forms could not be distinguished from those of their Mediterranean neighbors. The thesis developed so impressively in The Theft of History was first aired in The Oriental, the Ancient and the Primitive (Goody 1990) and the violence done to Asian societies by Euro-centric historiography received a comprehensive rebuttal in The East in the West (1996). More recently, Goody has extended this line of thought in two directions: Islam in Europe (2004) documents the cultural debt Europeans owe to the Islamic world; and Renaissances (2010) argues for the Italian Renaissance's dependence on non-European cultural sources, while demonstrating comparable historical phenomena in China, India, and the Middle East. The first of these goes over historical ground that is quite well known to academics, if not to neoconservatives inspired by Samuel P. Huntington's (1996) thesis concerning "the clash of civilizations." The second is a lengthy development of the argument in The Theft of History bringing together the fruits of Jack Goody's eclectic scholarship in a refreshing and insightful way (Burke 2009).

Islam in Europe was written in the context of the launch of the War on Terror and the invasion of Iraq. Jack Goody is not usually thought of as a public intellectual, unlike his friend and contemporary Eric Hobsbawm with whom he shared so much. But, as the Preface to Production and Reproduction (1976) shows - and the Preface to Metals, Capitalism and Culture (2012) echoes - his work has always been inspired by personal 
engagement and political commitments. It is hard to imagine how he could have summoned the energy for such an extended series of books if he were not motivated in some way to change the world. Here he is not just content with showing Europe's debt to Islam, but he also addresses questions of legitimate violence, ethnic cleansing, and terrorism while drawing attention to the palpable presence of Muslims in Europe as immigrants in their millions. This short book is a rare public intervention, but it is grounded in the convictions of a lifetime.

Renaissances: The One or the Many? (2010) links Goody's concern with human culture to the subject of the next section: how did the Italian Renaissance contribute to economic development, as well as to the arts and sciences, and does this constitute sufficient grounds for Europe to make an exclusive claim to be the original source of both modernity and its engine, capitalism. He rejects all these claims as a specious teleology projected backwards in history by people of European descent basking in their temporary global supremacy in the 19th and 20th centuries. Capitalism and modernity both originated in Bronze Age revolutions in which all Eurasian civilizations participated and especially to the invention of writing, which made a material object out of language. The Italians drew liberally on Arab and even Indian and Chinese sources. In his multi-volume A Study of History (1948), Arnold Toynbee referred to the humanist revival of a dead "classical" tradition as "a recurrent phenomenon" in world history; and Jack Goody takes advantage of the recent efflorescence of academic scholarship to document and analyze a number of these. To repeat, the tradition of Western exceptionalism is still alive and well, including in anthropology itself.

\section{Capitalism: between Agrarian civilization and the Machine Revolution}

The first and last of the books reviewed here, Capitalism and Modernity (2004) and Metals, Capitalism and Culture (2012), frame the most ambitious task that Jack Goody has set himself since the millennium: to replace the world vision of the founders of modern social theory, especially as typified by the followers of Karl Marx and Max Weber. Much of his writing, as we have seen, is deconstructive in style. Moreover, he is not one for making programmatic statements that can easily be reproduced as sound bites and iconic categories by adepts. His books' arguments are often made in a roundabout way, nuanced and embedded in thick description. It is no coincidence that his occasional prefaces offer more clues of his general program than the texts themselves. In particular, his emphasis on the agrarian roots of the modern world tends to marginalize the historical trends of the last two centuries that many would consider to be more germane to our current global predicament. 
Capitalism and Modernity: The Great Debate (2004) is the weakest of the books reviewed here. Goody opens with a sketchy review of the theoretical issues involved in "the culture of capitalism" and "modernization." Then he bases an account of culture and economy in Europe on a detailed rejection of Landes' (1998) "europhile" attempt to explain why Britain succeeded in launching an industrial revolution, building on Europe's allegedly unique economic advantages. The case against "Eurocentric historians" is made through J. M. Blaut (2000), even though we now know that Jack Goody would soon afterward launch his own masterpiece on this topic. Thomas Malthus (1798) then acts as a bridge to European prejudice concerning the East and China in particular. Goody's introduction of China's challenge to prevailing conceptions of the world economy draws mainly on Kenneth Pomeranz' (2000) excellent book, The Great Divergence. Only after this selective digest of the literature, do we come to the last and longest chapter, "The Growth and Interchange of Merchant Cultures," which addresses the core of Goody's argument that Western industrial capitalism did not differ significantly from its merchant capitalist predecessors around the world.

Jack Goody addresses Marx (1867) on capital directly, but mainly to dispute his account of merchant capitalism and his assumption that British industrialization had uniquely global significance. Goody's arguments and evidence are forceful and erudite; they should modify any serious reader's preconceptions concerning economic history. But Marx's typology of finance, merchant, and industrial capital is nowhere considered systematically and it should have been. Making money with money through interest-bearing loans is as old as civilization, says Marx. So is the use of capital in trade, where profit comes from buying cheap and selling dear. Manufacturing industry recurs in world history, not least, as Goody shows, in China, which, at the time Malthus wrote his essay, was at least on a par with Europe. The 19th century was a turning point, according to Marx, because "industrial capital" became the driver of the world economy, starting in Britain. "Industrial" refers not to mining and manufactures as such, but to the deployment of capital to hire wage labor on a large scale, adding machines to their production. It can take place in agriculture, industry, or services. For Marx, this constitutes a breakthrough since labor is the only commodity capable of producing more than it costs. Moreover, when the bulk of the population works for wages, the market for their means of livelihood is vastly expanded. The industrial demand for wage labor requires a mass exodus from the land. Jack Goody is on strong ground when he insists that Britain's and Europe's advantage was temporary. This is already a fait accompli. But he does not have much to offer in the way of explanation for the shift of human production and livelihood from the countryside to the city in the last two centuries.

Metals, Culture and Capitalism (2012), on the other hand, is a tour de force, full of astonishing insights and new arguments. Why metals, which never made an appearance until now? Because Jack Goody discovered that 
Bronze Age civilizations, the crux of his thesis concerning Eurasia's unitary identity, had no bronze! From this observation he infers a theory of uneven development of startling originality. Lowland Mesopotamia and other urban centers had to import metals from barbarian highland areas, such as Anatolia and Germany. In time, the mineral exporters were able to copy the tools and weapons of the city-dwellers and this enabled them eventually to turn the tables in cyclical fluctuations over long periods. This is reminiscent of Ibn Khaldun's (2004) 14th-century analysis of the periodic reversal of fortunes between sedentary coastal and riverine cities and nomadic desert tribes in the Muqaddimah. And, of course, it provides a compelling bridge to Goody's vision of the contemporary world economy as multipolar, in contrast with the unipolar version the Europeans made a century or more ago. Industrialization likewise relies heavily on minerals and offers many examples of the alternation and reverses characteristic of uneven development.

The book has three sections: on metals in the ancient world, featuring mainly the Middle East and the Mediterranean; a much more elaborate discussion of merchants than in the earlier book, focusing again on the Middle East and China, but this time on Venice too; and finally a shorter section on iron and the industrial revolution with a rich concluding chapter linking capital accumulation and renaissances through metals, to which I turn in Part 4 below. Metals is an extraordinary achievement, offering a window on all that went before that renews Jack Goody's book series in its entirety.

I have considerable sympathy for the notion that the agrarian origins of modern civilization are more important than they are often taken to be. Marx himself, while seeking to identify the novel features of industrial capitalism, was open to suggesting than capitalist labor relations were feudalism in drag. As we have seen, for Goody the industrial revolution did confer definite advantages on the West, even if this did not justify the historical projections that they built on the basis of that temporary ascendancy. He does believe, however, that the recent shift in economic power to Asia was inevitable, given their shared institutional heritage of the Bronze Age urban revolution. He evoked the issue of industrialization toward the end of The Theft of History, showing that manufactures on a large scale can be found in Asia too at various times in the past, as well as in the present. But when he extends his thesis concerning agrarian civilization to the last two centuries, he is less convincing. Thus he says in passing, of China's leading role in world economy today, "This latest shift has been carried out by a communist government, without much deliberate help from the west" (2006:286). This is simply untrue. Unlike India, which pursued a path of technological and financial self-sufficiency after independence, China's transition to capitalism has been fueled by massive technology transfers and capital investment from the West. Now that I have read Metals, however, I feel compelled to revisit these arguments with a fresh perspective in mind.

Childe himself did not assimilate the machine revolution of industrial capitalism to what emerged in Mesopotamia five millennia ago. Since 1800, 
the explosion of population and cities has been fueled by the conversion of inanimate energy by machines, with the result that many people live longer, work less, and spend more than they ever did before. Goody is right to insist that the legacy of agrarian civilization is still strong in our world and that older forms of capitalism (merchant and financial) have not been swept aside by factory production. But we still need to understand the economic revolution we are living through, if only to head off global disaster. Marx and Weber have more uses in this respect than as mere cheerleaders for Western hegemony.

Marx, for all his occasional references to Asia's stagnation, explicitly did not reduce the capitalist mode of production to a case study of Western history. He saw in Victorian capitalism the seeds of a new stage in human history and identified the complex of workers, machines, and money that drove it. Since he was right, we might pay attention to his theoretical model. Goody's elision of any significant difference between merchant and industrial capital makes that impossible. Nor was Weber just concerned with the role of the protestant ethic in the rise of capitalism. Goody is probably right to disparage the results of his excursions into Asian religion; but Weber's General Economic History (1922) contains much that is also essential to understanding modern capitalism as an economic system.

\section{Jack Goodys's contribution to anthropology}

Jack Goody has been trying to lift his profession out of a myopic ethnography into a concern with the movement of world history that went out of fashion with the passing of the Victorian founders of anthropology. In Britain, this shift is conventionally represented as Malinowski's ousting of Frazer from national leadership. And Goody (1995) has left his own idiosyncratic memoir of that transition. He started out as Meyer Fortes' protégé at Cambridge, working as an ethnographer in the same region of Northern Ghana; and Cambridge, specifically his college, St. John's, has provided him with a base to this day. He kept up an active research interest in Ghana for a number of decades, much of that time in partnership with Esther Goody (Hart 1985). But from the 1960s he sought to integrate anthropology into history and the social sciences more generally. Whereas Fortes, his predecessor as head of the Cambridge department, had been keen to establish the disciplinary limits of anthropology, Goody reveled in its potential as an anti-discipline. He cared less about the boundaries between "academic fields of enquiry" than about the freedom to pursue important questions wherever they took the investigator (Goody 1991).

In the process, he developed a unique personal style that has more than an echo of the great Victorians in it. We know that he read and enjoyed Sir James Frazer's (1890) The Golden Bough as an Italian prisoner of war; and "the development of human culture" is reminiscent of E. B. Tylor (1871), 
who made the concept the centerpiece of his anthropology. Both men wrote compendious books of some literary merit using documentary sources drawn from all over the world. And why not? Their subject was after all the history of world society; but their approach was idealist. Goody's was drawn from Childe's materialist synthesis of the two great revolutions - the "neolithic" 10,000 years ago and the "urban" 5,000 years ago — which, with the industrial revolution, marked definitive stages in the history of human production and society.

Jack Goody, if not uniquely among his contemporaries, then with more persistence and range than other anthropologists, has pursued one tradition of investigating the movement of world history - the anthropology of unequal society - that largely fell into abeyance in the late 20th century and has precious few adherents today. David Graeber (2011) stands virtually alone as a recent exception. I have suggested that he did so largely as an outcome of his personal engagement with the formation of a new world society during and after the Second World War. His contribution lies mainly in using the regions of the Old World to show that inequality was global in scope. Do his studies of kinship, production, and communication in pre-industrial Africa and Eurasia point to some of the salient features of contemporary world society, even if, until The East in the West (1996), he never made such an issue the explicit object of his inquiries?

Goody's contrast between Eurasia and Africa reminds us of the durable inequalities of our world and suggests that the reasons for them may be less tractable than we like to think. At the same time, the rise of India and China underlines his warning against European complacency. The world is now simultaneously more connected than ever and highly unequal. A popular scientific text (Barabasi 2002) helps us to understand why this may be so. Left to their own devices, "scaled networks", exhibit a "power rule" in which a few hubs are highly connected and most nodes are only weakly connected. That is, the proliferation of networks, as in world markets today, would normally produce a highly skewed distribution of participants. The reduction of national political controls over global markets in the last two decades seems to have accelerated the gap between the haves and the have-nots everywhere, generating huge regional disparities in the process (Hart 2001). The task of devising institutions capable of redressing this situation seems further away today that it did in 1945, when Jack Goody set out on his post-war journey.

The ethnographic revolution was in part a way of rejecting this evolutionism, but, as Goody shows, the contrast between Western civilization and its primitive, non-industrial or non-Western antithesis survived. In the last half-century, he and Eric Wolf stand out as anthropologists engaged with the history of inequality in global terms. Indeed Goody acknowledges Wolf's (1982) preference for "tributary states" over the traditional opposition between Western feudalism and Asiatic despotism. Their methods and emphasis could not be more different; but each succeeded in replacing a 
cultural anthropology of infinite variations with a materialist world history illuminating the sources of humanity's current discontents.

Metals, Capitalism and Culture, however, makes it clearer than ever before that Jack Goody's approach has never been narrowly materialist. It is rather profoundly dialectical. His sustained attack on binary oppositions of all kinds, especially those underpinning Western claims to global hegemony, is not intended to replace an idealist emphasis on "culture" with one that isolates technology as causal. Rather he wishes to retain both poles of an opposition in movement, the better to understand the fluctuations of history in what one commentator has called l'bistoire pendulaire (Verdrager 2010). I choose to end this review with some extended excerpts from his last book. Let the writer speak in his own voice.

Academic study always has a tendency to drift away from its more practical cousin, technology, pulled aside by the existence of literacy and a scholarly elite; in this way "science" became concerned with the more abstract topics and with more general subjects like the order of the world, which had previously been the domain of religions.... We have to think of the Age of Metals not only in terms of technology but of art, as at Ur in the Ancient Near East. That problem continues. What is the connection between the Industrial Revolution, with its use of coal, coke and steel, and the European Renaissance with its flowering of the arts and other forms of knowledge? In Europe, that expansion was clearly an aspect of the limited secularization of society that I have mentioned. (Goody 2012:297)

The balance in [technological] achievements went back and forth, as they continue to do today. Europe and Eurasia are much more the context of "modernization" than Anglo-Saxon historiography allows. The current prominence of Germany and China is nothing new, but part of this alternation between roughly equivalent societies. Neither Protestantism nor Catholicism, Islam nor Buddhism had a permanent advantage; all participated in some measure. The theme of this book has been central to my thinking. Not only has it tried to link up East and West but also to associate culture and industry, which have been hopelessly divided (Goody 2012:299).

The idea that Europeans invented a new form of rationality or even social change itself was a product of their temporary superiority in the 19th century and the attempt to explain why until then others had not achieved what they had done. However, invention is not something that is alien to any human mind, nor yet is rationality; they appear throughout human existence in different forms, at different tempos, and in different mixes. From the very beginning humans have invented solutions to their problems and they have explored the world around them, often ending with transcendental visions. The idea of an earlier, static, "primitive," non-rational society has been maintained by many sociologists and historians, including Marx and Weber, but it is quite foreign to most of those who have engaged in "participant observation" among such peoples.... Advances [in mining] were normally the result of multitudes of small steps 
taken with the aid of the pragmatic ingenuity of generations of working miners rather than giant leaps facilitated by scientific breakthroughs. The same was true of agriculture. Life has not changed in this respect. Man is a "rational" animal, whatever that may imply, and rationality is not simply an attribute of modern man, though with writing and computers he may have become more "rational" in terms of an array of more limited and obvious criteria. (Goody 2012:290).

Jack Goody remains to this day an anthropologist whose sensibility was formed by long-term ethnographic fieldwork. But he knew that, if he aspired to throw light on the human predicament as a whole, he would have to become a world historian too. In both respects, the questions he pursued were formed by his experience of and engagement with the unequal world that is emerging in our times. It is a world less modern than the inmates often seem to think. At 95, with a score of books under his belt in this series, Jack Goody does not offer final answers to his guiding questions. But he surely has come a long way and, thanks to his efforts, so might some of the rest of us, if we follow his example.

\section{Acknowledgments}

I consider myself to be an open source intellectual. This is the last in a trilogy of articles I have written on Jack Goody, its predecessors being Hart (2006, 2011a). I have already published reviews of two of the books considered here (Hart 2007, 2011b). I have drawn liberally on these previous publications in writing this review article, which places his books of the last decade within the framework of his project of world-historical comparison as a whole. Its structure and much of the content, however, is original. Several pieces posted on my website (http://thememorybank.co.uk) address Goody's work in ways that overlap with the above. I have never seen the point of trying to make each step in a lifelong journey toward discovering the meaning of my teacher's extraordinary output entirely separate from the rest. Only the principal beneficiaries of academic publishing's current intellectual property regime might contest this strategy.

\section{References cited}

Anderson, P.

1974 Passages from Antiquity to Feudalism. London: Verso.

Barabasi, A-L.

2002 Linked: The New Science of Networks. Cambridge, MA: Perseus.

Bernal, M.

1987 Black Athena: The Afro-Asiatic Roots of Classical Civilization. London: Free Association Books. 
Blaut, J. M.

2000 Eight Eurocentic Historians. New York and London: Guilford.

Braudel, F.

1981-1984 Civilization and Capitalism: 15th to 18th century (3 vols.). London:

Phoenix.

Burke, P.

2009 Jack Goody and the Comparative History of Renaissances. Theory, Culture

\& Society 26(7-8): 16-31.

Childe, V. G.

1954 [1942] What Happened in History. Harmondsworth: Penguin.

Elias, N.

1994 [1939] The Civilizing Process. Oxford: Blackwell.

Engels, F.

1884 The Origin of the Family, Private Property and the State. London: Lawrence and Wishart.

Finley, M.

1973 The Ancient Economy. London: Chatto and Windus.

Fortes, M., and Evans-Pritchard, E., eds.

1940 African Political Systems. London: Oxford University Press.

Frazer, J.

2009 [1890] The Golden Bough: A Study in Magic and Religion. London: Oxford Paperbacks.

Goody, J.

1962 Death, Property and the Ancestors: A Study of the Mortuary Customs of the LoDagaa of West Africa. Stanford, CA: Stanford University Press.

1971 Technology, Tradition and the State in Africa. London: Oxford University Press.

1976 Production and Reproduction: A Comparative Study of the Domestic Domain. Cambridge: Cambridge University Press.

1977 The Domestication of the Savage Mind. Cambridge: Cambridge University Press.

1983 The Development of the Family and Marriage in Europe. Cambridge: Cambridge University Press.

1990 The Oriental, the Ancient and the Primitive. Cambridge: Cambridge University Press.

1991 Towards a Room with a View: A Personal Account of Contributions to Local Knowledge, Theory, and Research in Fieldwork and Comparative

Studies. Annual Review of Anthropology 20:1-23.

1995 The Expansive Moment: The Rise of Social Anthropology in Britain and Africa, 1918-70. Cambridge: Cambridge University Press.

1996 The East in the West. Cambridge: Cambridge University Press.

2004 Capitalism and Modernity: The Great Debate. Cambridge: Polity.

2004 Islam in Europe. Cambridge: Polity.

2009 The Eurasian Miracle. Cambridge: Polity.

2010 Renaissances: The One or the Many? Cambridge: Cambridge University Press.

2012 [2006] The Theft of History. Cambridge: Cambridge University Press. 
2012 Metals, Capitalism and Culture: An Essay on the Origins of the Modern

World. Cambridge: Cambridge University Press.

Graeber, D.

2011 Debt: The First 5,000 Years. New York: Melville House.

Hann, C.

2008 Reproduction and Inheritance: Goody Revisited. Annual Review of Anthropology 37:145-158.

Hann, C., and Hart, K.

2011 Economic Anthropology: History, Ethnography, Critique. Cambridge: Polity.

Hart, K.

1985 The Social Anthropology of West Africa. Annual Review of Anthropology $14: 243-272$.

2001 Money in an Unequal World. New York: Texere. First published in 2000 as The Memory Bank, 2000. London: Profile. http://thememorybank.co.uk/book 2006 Agrarian Civilization and World Society. In Technology, Literacy and the Evolution of Society: Implications of the work of Jack Goody. D. Olson and M. Cole, eds. Pp. 29-48. Mahwah, NJ: Lawrence Erlbaum.

2007 The World in Time-Space: About Jack Goody, The Theft of History. European Journal of Sociology 48(3):437-443.

2009 Money in the Making of World Society. In Market and Society. C. Hann and K. Hart, eds. Pp. 91-105. Cambridge: Cambridge University Press.

2010 Africa's Urban Revolution and the Informal Economy. In The Political Economy of Africa. V. Padayachee, ed. Pp. 317-388. London: Routledge.

2011a Jack Goody's Vision of World History and African Development Today (Goody Lecture 2011). Halle: Max Planck Institute for Social Anthropology. http:// www.eth.mpg.de/cms/en/research/d2/multimedia/Hart_Goody_Lecture.pdf 2011b Review of Jack Goody's The Eurasian Miracle. Critique of Anthropology 31(2):156-158.

Huntington, $\mathrm{S}$.

1996 The Clash of Civilizations and the Remaking of World Order. New York:

Free Press.

Ibn, Khaldun.

2004 The Muqaddimah: An Introduction to History (Abridged). Princeton, NJ:

Princeton University Press.

Landes, D.

1998 The Wealth and Poverty of Nations: Why Some Nations Are So Rich and

Some So Poor. London: Little, Brown.

Latour, B.

1993 We Have Never Been Modern. Amsterdam: Harvester.

Lévi-Strauss, C.

1962 La Pensée Sauvage. Paris: Plon.

Malthus, T.

1958 [1798] An Essay on the Principle of Population. London: Dent.

Marx, K.

1970 (1864) Capital, vol. 1. London: Lawrence and Wishart.

Morgan, L. H.

1964 (1877) Ancient Society. Cambridge, MA: Belknap. 
Murdock, G. P.

1967 The Ethnographic Atlas: A Summary. Ethnology 6:109-236.

Needham, J.

1954-2004 Science and Civilization in China (7 vols.). Cambridge: Cambridge

University Press.

Polanyi, K.

1957 The Economy as Instituted Process. In Trade and Market in the Early

Empires. K. Polanyi, C. Arensberg, and H. Pearson, eds. Pp. 243-269. New York:

Free Press.

Pomeranz, K.

2000 The Great Divergence: China, Europe and the Making of the Modern World

Economy. Princeton NJ: Princeton University Press.

Rousseau, J-J.

1984 (1754) Discourse on Inequality. Harmondsworth: Penguin.

Sombart, W.

1902-1927 Der Moderner Kapitalismus (3 vols.). München/Leipzig: Duncker \&

Humblot.

Toynbee, A.

1987 [1948] A Study of History (abridged). Oxford: Oxford University Press.

Tylor, E. B.

1871 Primitive Culture: Researches into the Development of Mythology,

Philosophy, Religion, Art and Custom. London.

Verdrager, P.

2010 L'histoire pendulaire de Jack Goody. Revue international des livres et des idées 14:63-85.

Weber, M.

1978 Economy and Society (2 vols.). G. Roth and C. Wittich, eds. Berkeley:

University of California Press.

Weber, M.

1981 [1921] General Economic History. New Brunswick, NJ: Transaction Books.

Wolf, E.

1982 Europe and the People without History. Berkeley: University of California

Press.

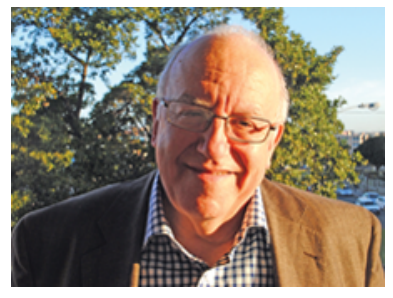

KEITH HART is Centennial Professor of Economic Anthropology at the London School of Economics and Political Science, and International Director of the Human Economy Program in the Centre for the Advancement of Scholarship at the University of Pretoria. He contributed the concept of the informal economy to development studies and has written at length on money in the digital revolution, including the collapse of the twentieth century's dominant form, national capitalism. He was a founder of the Open Anthropology Cooperative (OAC). His publications include: The Human Economy: A Citizen's Guide (edited with J.-L. Laville and A.D. Cattani, 2010) and Economic Anthropology: History, Ethnography, Critique (with C. Hann, 2011). 